\title{
The Enforcement of Option
}

\section{Agreements}

$\mathrm{I}^{\mathrm{N}}$

RECENT years, as property values have increased and the institution of business enterprises has become more frequent, the granting of options or refusals for the purchase of property has come into common use. As yet, however, the decisions are not altogether harmonious either as to the nature of such agreements, or as to the powers of the courts to enforce them. This uncertainty in the law is increased by the tendency on the part both of courts and of text writers, to speak of options given for a consideration, as irrevocable during the period for which they are granted. No distinction is made between the power and the right to revoke the offer, the inference being usually left that there is something in the nature of an option, when based upon a consideration, that leaves the person granting it powerless to interfere. ${ }^{x}$

Probably the clearest distinction between options and other agreements pertaining to the sale of property is that found in the Montana case of Ide v. Leiser. ${ }^{2}$ The court in that case says: "There may be (1) a sale of lands, (2) an agreement to sell lands, (3) what is popularly called an option. The first is the actual transfer of title from grantor to grantee by appropriate instrument of conveyance. The second is a contract to be performed in the future which, if fulfilled. results in a sale . . The third, an option, originally is neither a sale nor an agreement to sell, it is simply a contract by which the owner of property agrees with another person that he shall have the right to buy his property at a fixed price, within a time certain." Frequently, the courts and text writers lose sight of this distinction and confuse an option based upon a consideration

${ }^{x}$ For instance of this misleading phraseology see 21 Am. \& Eng. Encyc. of Law, p. 929; 9 Cyc. 286; Anson on Contracts, (Knowlton's 2nd Am. Ed.), p. 35, note.

2 (1890) 10 Mont. 5; 24 P. 695; 24 Am. St. R. 17. 
with an agreement to sell upon condition. ${ }^{3}$ Thus, we find one eminent authority saying that "where the offer is under seal, or is founded on a consideration, it has become more than an offer, it has become a promise upon condition."

It is submitted, however, that an offer in the form of an option does not suffer a metamorphosis into a promise upon condition simply because of the presence of a consideration. Let us take the simplest case. that of an option for a certain period given without consideration. Clearly, such an offer not only can, but may rightfully be, revoked at any time before it is accepted. And a sale to a third person would amount to a revocation, especially if the fact of such sale were known to the person holding the option before he accepted it. ${ }^{5}$ Just as clearly, on the other hand, would there be a binding contract if the offer contained in the option were accepted before it was revoked. As the Supreme Court of Massachusetts said in an early case, "Though the writing signed by the defendants was but an offer, and an offer which might be revoked, yet while it remained in force and unrevoked, it was a continuing offer during the time limited for acceptance, and during the whole of that time it was an offer every instant; but as soon as it was accepted, it ceased to be an offer merely, and then ripened into a contract." ${ }^{\circ}$ To use the apt language of another court, "It is the acceptance while outstanding which gives an option not given upon a consideration its vitality." "

So much for the option given without consideration. Suppose, however, that a consideration be given for the option. The only difference in the situation would' seem to be that the offeror cannot now retract his offer within the stipulated time without rendering himself liable in an action for damages. ${ }^{8} \mathrm{We}$ need not adopt Mr. Justice Holmes' theory that a contract is

${ }^{3}$ O'Brien v. Boland (1896), 166 Mass. 481,44 N. E. 602; Guyer v. Warren (1898), 175 I1l. 328, 51 N. E. 580; Corson v. Mulvany (1865), $49 \mathrm{~Pa}$. St. 88, 88 Am. Dec. 485.

4 Prof. John D. Lawson in 9 Cyc. 287.

Dickinson v. Dodds (1874), 2 Ch. D. 463; Coleman v. Applegarth (1887), 68 Md. 21, 11 Atl. 284.

6 Boston R. Co. v. Bartlett (1849), 3 Cushing 225.

${ }^{7}$ Bradford v. Foster (1888), 87 Tenn. 8, 9 S. W. 195.

8 McMillan v. Ames (1885), 33 Minn. 257, 22 N. W. 612; Baker v. Shaw (1912), 68 Wash. 99, 112 P. 611; Willard v. Tayloe (1869), 8 Wall. 557, 75 L. Ed 501; Vassault v. Edwards (1872), 43 Cal. 458. 
merely "the taking of a risk," $\bullet$ and that a person making the offer contemplates, primarily, the payment of damages rather than the performance of his promise, in order to escape the other extreme, that the offer under such circumstances is irrevocable. For if that theory were correct, decrees of specific performance would be anomalous. On the other hand, the theory that the existence of consideration renders an offer irrevocable, would likewise present us with an instance of a legal anomaly, an unbreakable contract. ${ }^{10}$ The only logical view would seem to be that an offer, when based upon a consideration, cannot be withdrawn within the time allowed for acceptance, regardless of whether or not it is actually accepted by the offeree, without rendering the offeror liable for damages. If the offer is accepted within the stipulated time, the presence or absence of consideration of course becomes immaterial.11 "When the option given upon a consideration is accepted within the time allowed, the offer and acceptance constitute a contract of sale, and the same result flows from the acceptance of an offer without consideration, if accepted before the offer is withdrawn or revoked." ${ }^{2}$ It would appear, therefore, that whether or not a consideration has been given for the option, is immaterial with respect to the question as to its revocability. It is equally revocable in either case, though the consequences of the revocation are very different in the two cases.

It is with reference to these consequences, it is when we come to the question of remedies open to the offeree for a revocation of an option, that we are confronted with difficulties. Clearly, as has been pointed out, where the option was given gratuitously, the offeree is remediless in the event that he learns that the offer has been revoked before he gives notice of acceptance. But where a consideration has been given, various questions present themselves. The point that principally troubled the courts for a long time when an action was brought by the offeree for specific performance, was the apparent lack of mutuality. Such cases seemed to be cases where one party

- Holmes, The Common Law, p. 300.

10 Langdell on Contracts, Sec. 178.

31 McMillan v. Ames (1885), 33 Minn. 257, 22 N. W. 612; Baker v. Shaw (1912), 68 Wash. 99, 122 P. 611.

12 Frank v. Stratford-Handcock (1904), 13 Wyo. 37, 77 P. 134, 67

I. R. A. 571 . 
was bound and the other was not. Many of the courts finally resolved the question of the validity of such agreements by looking for a consideration, and upon finding that, upholding the agreements themselves. Thus, we find the Illinois Supreme Court saying: "The doctrine of the earlier English and American cases, in which it was held that the want of mutuality of obligation and remedy would render the contract incapable of specific enforcement, has by the more modern cases been so modified that optional agreements to convey without any corresponding obligation or covenant to purchase will now be specifically enforced in equity, if made upon sufficient and valuable consideration. and so where the agreement to convey is a part of a lease or other contract between the parties for which the agreement to convey forms the true consideration, the want of mutuality will not void the contract."13 With respect to the view thus expressed by the Illinois court, it may be said that it is difficult to see how the fact that the offeree has paid something to have the offer kept open for a certain period during which he may deliberate as to whether or not he cares to accept, can obviate the objection that before he actually accepts, mutuality is lacking. A more logical holding is that where the offeree has actually accepted the offer in due time, by beginning suit upon it, such action supplies the missing element. ${ }^{14}$ Merely filing suit would, however, appear to be ineffectual, unless such action be taken within the time provided in the option for acceptance, though this requirement is not emphasized in the cases enunciating this doctrine. Some authorities escape the difficulty by holding that the doctrine of mutuality is altogether inapplicable in cases of this kind. ${ }^{15}$

Generally, the action brought by the offeree is for the speci-

13 Hayes v. O'Brien (1891), 149 I11. 403, 26 N. E. 601, 23 I. R. A. 555; also see Estes v. Furlong (1871), 59 Ill. 298; Hawralty v. Warren (1866), 18 N. J. Eq. 124; Hall v. Center (1870), 40 Cal. 63; Clason v. Bailey (1817), 14 Johns. 484.

1t Vassault v. Edwards (1872), $43 \mathrm{Cal}$. 458; Woodruff v. Woodruff (1888), 44 N. J. Eq. 349, 16 Atl. 4; Conner v. Clapp (1906), 42 Wash. 642, 85 P. 342; Black v. Maddox (1898), 104 Ga. 157, 30 S. E. 723; Central Land Co. 7 . Johnson (1897), 95 Va. 223, 28 S. E. 175 . It will be found, upon investigation, that a great many of the cases cited as upholding this doctrine merely involve a question of compliance with the statute of frauds.

${ }^{15} \mathrm{Cf}$. Ames, Cases in Equity Jurisdiction, p. $430 \mathrm{n}$. and cases cited. 
fic performance of the option agreement. Where due acceptance of the offer has been made, such action would seem to be proper, assuming that the facts otherwise bring the case within the rules governing that subject. Whether consideration has been given for the option or not, is a matter of indifference in cases of acceptance before revocation, except insofar as the absence of consideration might influence the court in the exercise of the discretion allowed it in granting the remedy of specific performance. ${ }^{18}$ While it is proper for a court of equity to take into account the absence of consideration in determining the exercise of its discretion, such absence should not, however, be regarded as changing the nature of the agreement and ipso facto raising a bar to such remedy, though it is sometimes so regarded by the courts. ${ }^{17}$

Frequently, where the offeror has, for a consideration, granted an option, and subsequently withdrawn his offer in express terms, it has been held that the offeree may yet maintain suit for specific performance. It may be questioned whether this view is not fallacious. Even where a consideration exists the offeror has the power, even though he may not have the right, to revoke his offer, and an option, notwithstanding the consideration, would seem to be only an offer. Where he does revoke it, there is nothing left for the offeree to accept, and accordingly no contract to be enforced. A court of equity, in such a situation, would both have to make a contract between the parties and then to decree its enforcement. ${ }^{18}$ This objection, however, is not usually considered by the courts. They hold, to use the language of the Massachusetts Supreme

${ }^{10}$ Frue v. Houghton (1882), 6 Colo. 318; Cheney v. Cook (1858), 7 Wis. 413; Perkins v. Hadsell (1869), 50 I11. 216.

17 Graybill v. Brugh (1893), 89 Va. 895,17 S. E. 558, 37 Am. St. Rep. 894; Litz v. Goosling (1892), 93 Ken. 185,19 S. W. 527, 21 L. R. A. 127; Warren v. Castello (1892), 109 Mo. 338, 19 S. W. 29; Bean v. Burbank (1892), $16 \mathrm{Me}$. 458, $33 \mathrm{Am}$. Dec. 681 .

18 It has been suggested (Ashley on Contracts, p. 27, n. 1), that equity might overcome this difficulty in analogy to the doctrine whereby promises to leave real property by will will be enforced after the death of the promisor. This suggestion appears unsound, as, in such cases, there is but one agreement involved,- the promisee has usually suffered a detriment which renders the promise of the other party binding. There remains nothing in such cases but the specific enforcement of the promise of the other person. In the case of an option, the objection is the absence of an acceptance of the offer. 
Court, that the offeree, in such a case, may "treat the withdrawal as inoperative." 18

Where, during the pendency of an option, the offeror retracts his offer by selling to a third person, the remedy of the offeree will depend upon the question whether the purchaser had notice or not. If the purchaser had no notice when he bought, the sale to him would seem to be valid, and this is universally accepted as law. If the option were really irrevocable, it is hard to see how this result could be reached. Even if the purchaser did have notice it could well be argued that such notice was of no importance. that it merely gave him information that his vendor by selling to him was rendering himself liable in an action for damages. The courts, however, quite generally, hold that a sale to such third party under such circumstances may be rescinded and a specific performance of the contract made by the acceptance of the option, required. This is apparently upon the theory that such third party takes the property impressed with a trust in favor of the optionee. ${ }^{20}$

Heretofore, in treating the question of options given for a consideration, it has been assumed that when the offer is under seal such seal is, if not conclusive, at least prima facie proof of consideration. Such has been the construction placed upon sealed instruments by most of the courts which have passed upon cases involving offers under seal, the rules necessarily varying with the statutory modifications that have been made of the common law doctrine of the effect of a seal. ${ }^{21}$ A few of the courts and text writers, however, apparently base their theory of the irrevocability of offers made under seal on the strict common law doctrine of covenant, in the absence of any statutes pertaining to the weight to be given to a seal. In other words, they stand upon the ground not that a seal imports a consideration, but that the offer is binding by reason of the form used. Thus, Professor Lawson says: "The common

19 O'Brien v. Boland (1896), 166 Mass. 481, 44 N. E. 602. This case, however, was in fact one involving a contract under seal. This presents a more difficult question which will be considered later.

20 Black v. Maddox (1898), $104 \mathrm{Ga} .157,30$ S. E. 723; Watkins v. Robertson (1906), 105 Va. 269. 5 I. R. A. N. S. 1194; Frank v. Stratford-Handcock (1904), 13 Wyo. 37, 77 Pac. 134, 67 L. R. A. 571; Hayes v. O'Brien (1891), 149 I11. 403, 26 N. E. 601.

21 Willard y. Tayloe (1869), 8 Wall. 557, 75 I. Ed. 501; McMillan v. Ames (1885), 33 Minn. 357, 22 N. W. 612. 
law rule that where an offer is made under seal it cannot be revoked, applies to options given under seal."22 Professor Ashley criticises the doctrine, insofar as options are concerned, on the ground that although, under the common law rule, a promise under seal may be binding. an offer is not a promise and hence is revocable. ${ }^{23}$ But clearly, where a time is stated during which the offeror agrees that he will keep the offer open, such statement is a promise, whether that particular word be used or not. And even if no time is stated during which the offer will be kept open, it would seem that the offeror, under the common law doctrine, would be bound upon an implied promise to keep the offer open for a reasonable period.

The doctrine of irrevocability of options under seal as stated by Professor Lawson is, however, subject to criticism from another direction. Even if we should concede that his theory is correct insofar as it determines the effect of a seal, it is misleading in that no qualification is made as to the remedies open to the offeree. As a matter of fact, specific performance of the agreement, the remedy most commonly asked for and allowed by the courts, will not lie where no consideration has passed, even where a seal is attached. ${ }^{24}$

It is finally submitted that this common law theory of the irrevocability of offers, when made under seal, is unsound for another reason. It is no doubt true that a seal does not import a consideration and that the correct theory of the binding force of a sealed instrument is that it is binding by reason of its form. This is obvious when we consider that a promise made under seal was binding long before the doctrine of consideration was dreamed of. But that should not blind us to the further fact that the idea that a seal does import a consideration has thoroughly permeated the courts both of this country and of England. Moreover, that idea underlies all of the statutes passed for the purpose of destroying the conclusive character of such presumption. Accordingly, whether the interpretation put by the courts upon the effect of a seal is in accordance with history and logic or not, the fact confronts 28.

229 Cyc. 289. Cf. Williston's Wald's Pollock on Contracts, p. 28 n.

28 Ashley, Contracts, p. 255.

24 Anson on Contracts; Huffeut's 2nd Am. Ed. p. 75. 
us that a seal is, today, generally regarded as evidence, prima facie, if not conclusive, of the existence of consideration. If we accept this general interpretation of the effect of a seal as correct, and if it be true, as suggested above, that an offer though based on a consideration is revocable, it follows that in no case can specific performance of an offer in the form of an option be granted where such offer prior to its acceptance has been revoked. ${ }^{25}$

ROBERT L. MCWILLIAMS.

Spokane, Washington.

25 Notwithstanding the theoretical difficulties pointed out in $\mathrm{Mr}$. McWilliams's article, - that an option is only an offer, though given for a consideration, and that the very idea of offer involves the ability of the offeror to revoke it, - the Supreme Court of California, at least, has pretty definitely committed itself to the view that such an option "cannot be withdrawn during the time agreed upon for its duration." W. G. Reese Co. v. House (1912), 162 Cal. 740, 745, 124 Pac. 442; Smith v. Bangham (1909), 156 Cal. 359; 28 L. R. A. (N. S.) 522, 104 Pac. 689.O. K. M. 